\title{
Mapping the intellectual structure of entrepreneurship in the light of dynamic capabilities: a bibliometric analysis
}

Giovani Cruzara ${ }^{1}$

Rivanda Meira Teixeira ${ }^{1}$

Vivien Kaniak ${ }^{2}$

Itamir Caciatori Junior ${ }^{1}$

\footnotetext{
${ }^{1}$ Escola de Administração / Setor de Ciências Sociais Aplicadas / UFPR - Universidade Federal do Paraná

${ }^{2}$ Ciências Sociais Aplicadas / Campus Curitiba-PR / Universidade Federal do Paraná
} 


\title{
MAPPING THE INTELLECTUAL STRUCTURE OF ENTREPRENEURSHIP IN THE LIGHT OF DYNAMIC CAPABILITIES: A BIBLIOMETRIC ANALYSIS
}

\begin{abstract}
This study uses a bibliometric approach to analyze how the scientific production of entrepreneurship and the theoretical approach of the dynamic capabilities is corelated. With a sample of 701 studies from the Web of Science database we identified 88 articles concentrated in four different journals, pointing the most productive authors, the most cited references and clusters of keywords mainly related to entrepreneurship and dynamic capabilities. The results demonstrates that entrepreneurship and dynamic capabilities are two research streams that still need to have their relationships better explored, since the bibliometric maps demonstrated that most studies appear to have a main focus on dynamic capabilities but only addressing entrepreneurship related either to the entrepreneur itself, or to its entrepreneurial orientation not exploring other important entrepreneurship issues. This work contributes theoretically as being the first bibliometric study that examines the relationship between entrepreneurship and dynamic capability and encourages future studies on the theme.
\end{abstract}

Keywords: Entrepreneurship. Dynamic Capabilities. Bibliometric.

\section{$1 \quad$ Introduction}

Entrepreneurship is a research field has been gaining prominence over the past years since its introduction over the 80's decade and started to gain more focus over the year of 2000, precisely when the works of Shane and Venkataraman (2000) and Sarasvathy (2001) were published at the Academy of Management Review. While the first proposed an integrating framework for the entrepreneurship field, the later assumed that entrepreneurship is a process that involves not just the individual characteristics of the entrepreneur, but the environmental characteristics that will also affect the outcomes of an entrepreneurial opportunity.

At the same time another theoretical approach was also gaining prominence at the academy over the past years when the concept of dynamic capabilities emerged from the work of Teece, Pisano and Shuen (1997), where the authors define the dynamic capabilities as being "The ability that the company has to integrate, built and reconfigure internal and external competences in order to address rapidly changing markets." (Teece, Pisano and Shuen, 1997:516). More specifically, the authors point that the dynamic capabilities are considered processes, which are shaped by the organization positions and its history.

The emergence of studies in dynamic capabilities is related to the efforts of researchers aiming to understand why some firms possess and sustain a competitive advantage, especially in markets of unpredictable and rapid changes (Petraf, Di Stefano and Verona, 2013). In this sense, seminal authors like Teece, Pisano and Shuen (1997) stated that the rational action of the managers had the fundamental role in innovating which is the key challenge of the organizational change. 
But it was only in 2006 that an study of Zahra, Sapienza and Davidsson (2006) proposed to join the ideas of entrepreneurship and dynamic capabilities in an article thar suggests that entrepreneurs have an important role as an agent of change, but that change should also be embedded in organizational routines in order to achieve a reconfiguration of the firm's resources. This study achieved such importance that according to Mota et al. (2017) the article is listed as one of the most cited references at the dynamic capabilities stream.

In this sense, dynamic capabilities is a theoretical approach that interconnects with the field of entrepreneurship, mainly to the fact that both dynamic capabilities and the exploitation of entrepreneurial approach are considered processes that involve not just the entrepreneur but the environment as well (TEECE, 2016). For this reason, studying the interconnection of the two concepts are vital to understand an enlarge the view of how the creation and use of dynamic capabilities can help companies to better perceive entrepreneurial opportunities, exploit them as well as undertake changes to implement new reconfigurations.

However, despite the importance of the themes and the high number of bibliometric studies addressing the two concepts separately, none specifically explored the field of entrepreneurship and dynamic capabilities together. Therefore, the present article aims to explore this gap as well as to list the main journals that publishes both matters, pointing the most productive authors, the most cited references and analyses the clusters of keywords mainly related to entrepreneurship and dynamic capabilities.

This paper contributes theoretically once it has no precedent bibliometric study in the current literature that examines the relationship between entrepreneurship and dynamic capability as a role consisting in a unique study that considers systematically the subjects. Its practical contributions include the encouragement for potential future studies.

This paper is structured as follows: Section two encompasses a review of bibliometric studies from the past years that focus the field of entrepreneurship and others that targets the field of dynamic capabilities. Section three details the methodological procedures of our study, followed by section four, where we discuss the results of the research. On section five we present the final considerations as well as the research limitations and future research directions.

\section{2}

\section{An Overview of Previous Bibliometric Studies on the Fields}

According to McBurney and Novak, (2002) bibliometrics is an approach to evaluate and monitor the progress of a discipline field. As the approach relies on statistical quantification of data, to have the analysis performed, such approach can only be used when a stream of research already has some sustainable literature that would provide a sample of statistical representation to perform the study (Diodato, 1994). In this sense, both entrepreneurship and dynamic capabilities separately, are research streams that already demonstrated such a sustainable amount of literature which resulted in a number of bibliometric papers published.

Regarding the dynamic capabilities, we identified 38 bibliometric studies at the WOS database using the search string ("dynamic capaiblit*" AND bibliometric*) in title, abstracts and key-words and key-words plus of the studies. Those papers encompass a very broad spectrum of research, ranging from studies that explore innovation system and ecosystems (Suominen, Seppanen, and Dedehayir, 2019), absorvitive capacity (Apriliyanti and Alon, 2017), global branding (Chabowski, Samiee and Hult, 2013) and also open innovation (Randhawa, Wilden and Hohberger, 2016). 
Most studies focus on the strategic management aspects like the ones of Fernandes et al. (2017) and Vogel and Guettel (2013), demonstrating that dynamic capabilities is a research stream with different emerging perspectives such as strategic learning and organizational change for example. On the overall, it can be stated that bibliometric studies that addressed the dynamic capabilities variy within their objective, but most of them focus on addressing aspects of dynamic capabilities by itself.

In relation to the field of entrepreneurship, a larger number of bibliometric studies was identified at the WOS database by using the string (entrepreneu* and bibliometric*), totalizing 151 studies. These bibliometric studies ranges from different aspects of entrepreneurship. Citing the most recent ones we found focus on aspects such as regional development (Dan and Goia, 2018), female entrepreneurship (Santos, Marques and Ferreira, 2018), social entrepreneurship (Dionisio, 2019), organizational failure and decline (Kuecher and FeldbauerDurstmueller, 2019), as well as ethical aspects (Vallaster et al., 2019) and internationalization (Baier-Fuentes et al., 2019).

The bibliometric studies of entrepreneurship present an opposite scenario to the ones on dynamic capabilities once the most recent studies does not rely solely on analyzing entrepreneurship by itself but they combine the field of entrepreneurship with some other area to be explored or they even remain restrict to some specific journals (Volery and Mazzarol, 2015), or to smaller time frames for the analysis (Perry et al., 2016).

We also identified that the number of bibliometric studies related to entrepreneurship at the WOS database increased over the past years, as demonstrated on figure 1, in which the distribution of bibliometric studies related to the field of entrepreneurship published at the WOS database over the last 5 years are displayed.

\section{FIGURE 1 - DISTRIBUTION OF ENTREPRENEURSHIP BIBLIOMETRIC STUDIES PER YEAR OF PUBLICATION AT THE WEB OF SCIENCE DATABASE}

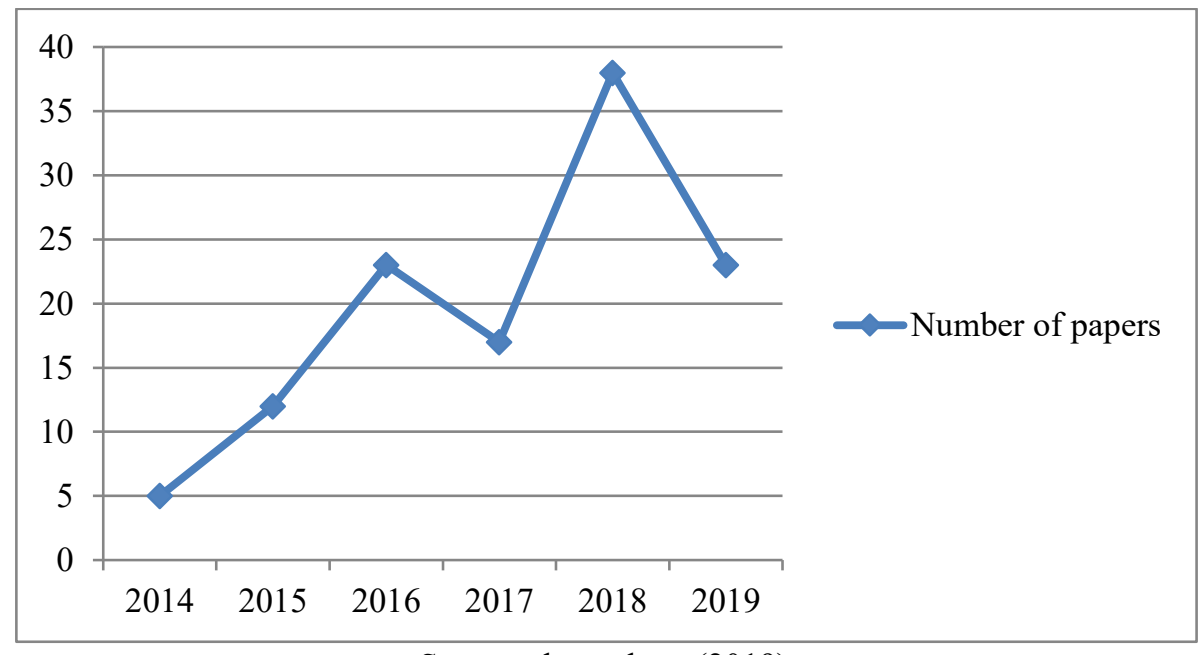

Source: the authors (2019).

Nevertheless, despite the increasing number of bilbiometric studies on the theme it was identified that none of them were addressing specifically entrepreneurship and dynamic capabilities together. 
Notwithstanding, in order to verify that indeed no other study recently published addressed the scenario that we aimed to address at the present paper, we also performed a search on the database with the string ("dynamic capabilit*" AND entrepreneu* AND bibliometric*). Even thou 8 studies were identified (Gomes et al., 2019; García-Lillo et al., 2017; Mota et al., 2017; Ferreira, Fernandes and Ratten, 2016; Vogel and Guettel, 2013; Benavides-Velasco, Quintana-García and Guzmán-Parra, 2013; Stefano, Gambardella and Verona, 2012) the analyses of the full text demonstrated that none of them specifically addressed the relationship between entrepreneurship and dynamic capabilities as the present study intended to investigate.

At the most recent study published, Gomes et al., (2019) performed an analysis related to the innovation ecosystem, in which, according to the authors, there is a research stream that draws from the previous business ecosystem literature. In this sense, their study focus neither on dynamic capabilities nor on entrepreneurship as its main line of inquiry. The dynamic capabilities appear on their research once the authors identify that this concept is often related to the business ecosystem and the concept of entrepreneurship was commonly found in the keywords of the analyzed papers, being often related to the concept of innovation ecosystem.

García-Líllo et al. (2017) focus on the 'born global firms', also known as 'international new ventures'. In this sense, entrepreneurship is pointed as a field of study in which this type of organization is often explored usually with studies addressing international entrepreneurship. Dynamic capabilities, on the other hand, are simply pointed as being used in some of the studies that the authors review.

The third paper analyzed was published by Mota et al. (2017) and focus more specifically on the dynamic capabilities stream, aiming to map the scientific landscape from 1990 to 2015. In this sense, the authors point to an increase on the number of publications over the past few years and that Business \& Economics and Engineering are the most important research streams, while the resource-based view and the neo-Schumpeterian approaches as its two main theoretical roots.

Ferreira, Fernandes and Ratten (2016) focus on the broad area of strategic management mapping its theoretical approaches which includes dynamic capabilities. They conclude that there is a division between strategic entrepreneurship and corporate entrepreneurship, but they do not establish a relation between dynamic capabilities and entrepreneurship.

Vogel and Güttel (2013) also investigated the field of strategic management but they focus specifically at the dynamic capabilities while at the strategic management field, analyzing the literature between 1994 and 2011. They highlight that the dynamic capabilities is related to learning and change capabilities which is also connected to firm performance, and aspects of organization theory and strategic management merges. Entrepreneurship, on the other hand, are only slighted mentioned, such as the entrepreneurial behavior, which according to the authors is a cluster that shares a common overlap with other clusters (such as sensing opportunities, and absorbing knowledge) when it comes to ambidexterity between exploration and exploitation.

The sixth study, published by Benavides-Velasco, Quintana-García and Guzmán-Parra (2013), deals with the research field of family business, with a review of literature that ranges from 1961 to 2008. In this sense, dynamic capabilities are identified in some studies of their sample and they state it as being a suitable theoretical perspective that can provide advances on the studies related to the family firms. Entrepreneurship appears with more emphasis on their study, once it connects with the scenario of family business. In this sense, the authors provide 
a list of journals that published more than 5 papers related to family business and a number of entrepreneurship journals can be identified such as: Entrepreneurship and Regional Development (5 papers); Journal of Business Venturing (25 papers); and Entrepreneurship Theory and Practice (55 papers). The high number of papers result in a topic named Entrepreneurship/innovation identified by the authors, with encompass studies that address entrepreneurship aspects within the family business organizations. Despite that, the study does not establish a direct relationship between dynamic capabilities and entrepreneurship.

Finally, the seventh study analyzed, published by Stefano, Gambardella and Verona (2012) focus on the sources of innovation for organizations, thus addressing technology and market demands. The dynamic capability is cited as the authors identified that they are central to their reviewed literature (the study of Teece, Pisano and Shuen (1997) was identified as being the most central reference to the sample collected). The authors mention that entrepreneurship plays a central role even though some literature addresses innovation and entrepreneurship in isolation. Nevertheless, dynamic capabilities and entrepreneurship are, again, explored in isolation from one another.

As demonstrated, none of the studies analyzed specifically addressed the theme of dynamic capabilities within the entrepreneurship field. Even though the keywords are accused on the search string the content of the articles do not reveal such parallel between the two streams of research which validates the uniqueness of the present research.

\section{$3 \quad$ Methodological Procedures}

For the present study, a bibliometric research method was chosen, once its approach is based on statistical techniques which permitted a clear visualization of the scientific field that correlates dynamic capabilities and entrepreneurship throughout bibliometric maps.

Bibliometric is known as an academic stream that seeks to evaluate the research developed by a scientific community in a specific research field (Gutiérrez-Salcedo et al., 2018). In line with that, the cited authors point that bibliometric technics are methods that aim to measure the research studies using scientific publications from bibliographic databases. In this sense, the availability of data enhances the aggregate data analysis, which provides the possibility of the creation of ideas for the researchers.

Other authors like Osareh (1996) had stated that bibliometric methods seek the improvement of scientific documentation, information and communication through the quantitative analysis of the academic works collections. The author explains that the bibliometric studies contributes to a better understanding of the scientific research field, analyzing it as set of social activities with the use of scientometrics techniques.

The citation traceability and the collaboration among researchers allow the consolidation of the bibliographic data exploration from the scientific research, as well as the orientation of these researches according to the most crucial study topics (ZUPIC; ČATER, 2015). The same authors also state that bibliometric studies are a complement, and not a substitute, of the traditional academic review methods, once it can provide analysis of academic fields by its structure categorizing them from countries, universities, and journals. In this sense, while traditional methods focus on analyzing the subjects in a more detailed way, the bibliometric techniques can cope with a large number of studies and generate different results representations, thus encompassing a broader level of analysis. 
The present study was based on Zupic and Čater (2015) five step model to conduct the research. The first step of the research design started with the following research question: How the scientific production on entrepreneurship field is correlated with the theoretical approach of the dynamic capabilities?

The second research step started with the definition of the keywords related to the areas to be explored. The present authors analyzed articles related both to dynamic capabilities and entrepreneurship, such as Zahra, Sapienza and Davidsson (2006) as well as other bibliometric studies that addressed either dynamic capabilities and entrepreneurship.

Then a search was conducted on the WOS database and the Scopus database in July 2019. The strings "dynamic capaiblit*" AND "entrepreneur*" were used to seek the keyword on the title, abstract, keywords and keywords-plus of the papers. The types of the documents selected were "article" and "review". In the search we identified 269 papers at the Scopus database, and 701 papers at the WOS database. Since WOS presented the greater number of results it was selected to be used as a database.

Information such as title, author, keywords, journal, year, abstract and references from these studies were gathered to analise the bibliographical coupling network and the impact measurement of the articles. After that, using the statistical software $\mathrm{R}$ and their bibliometrix package, an analysis was conducted. In this stage the researchers eliminated the inconsistencies of the databases, such as blank fields, and invalid data.

In the following step, named visualization, two stages were accomplished. In the first stage we generated and compiled the statistical data from the databases using the bibliometrix package ( $\mathrm{R}$ software). At that time, we also created tables with the most cited papers, collaboration indicators between authors, and indications of countries and research centers affiliations. On the second stage, we generate a bibliometric map using the VOSviewer software. The tool was created by Van Eck \& Waltman (2010) and enables the data graphic visualization on the labels, density and cluster mappings and also dispersion levels. Furthermore, the VOSviewer is useful considering the items distances from a multidimensional scaling. In this sense, the more the items are quoted together, the stronger is the relationship between then and the closer is their position to one another. It permits to demonstrate graphically how many citations the items received individually. Thus, the more the item is cited (e. g. papers, authors, journals, etc.), the larger is the size of the circles where its inserted (VOSVIEWER MANUAL).

\section{$4 \quad$ Results and Discussion}

Concerning to the concentration of articles by journal, 88 papers $(12.6 \%)$ of the 701 documents from WOS database are from four different journals, as it is demonstrated at Table 1.

TABLE 1 - JOURNALS THAT PUBLISHED THE MOST

\begin{tabular}{llllllll}
\hline \multicolumn{1}{c}{ JOURNAL } & NUMBER & & & & \\
& OF & $\mathbf{2 0 1 5}$ & $\mathbf{2 0 1 6}$ & $\mathbf{2 0 1 7}$ & $\mathbf{2 0 1 8}$ & $\mathbf{2 0 1 9}$ \\
& PAPERS & & & & & \\
\hline Journal of Business Research & 29 & 0 & 10 & 0 & 5 & 5 \\
Strategic Entrepreneurship Journal & 20 & 0 & 3 & 4 & 2 & 1 \\
\hline
\end{tabular}




\begin{tabular}{ccccccc} 
Industrial Marketing Management & 22 & 0 & 1 & 3 & 7 & 2 \\
Small Business Economics & 17 & 2 & 1 & 0 & 3 & 1 \\
TOTAL & $\mathbf{8 8}$ & $\mathbf{2}$ & $\mathbf{1 5}$ & $\mathbf{7}$ & $\mathbf{1 7}$ & $\mathbf{9}$ \\
\hline
\end{tabular}

Source: the authors (2019).

As demonstrated in the results the period between the 2015 and 2018 registered the most significant increase in the number of papers in the area. The journal that published the most was Journal of Business Research with 29 articles followed by the Strategic Entrepreneurship Journal with 20. The Industrial Marketing Management launched a special issue in October/2018 about Capabilities in business relationships and networks which became responsible for the concentration of 7 publications.

An analysis on the relationship between the papers and their references was also conducted and showed that from the 8.571 bibliographical references of the 701 papers, Teece is the most cited author followed by Eisenhardt as is it displayed on table 2:

TABLE 2 - MOST CITED REFERENCES

\begin{tabular}{lcc}
\hline Cited References & Local Citations & Citations in WOS \\
\hline Teece Dj, 1997 & 506 & 9,54 \\
Eisenhardt Km, 2000 & 350 & 4,772 \\
Barney J, 1991 & 297 & 16,401 \\
Teece Dj, 2007 & 265 & 2,788 \\
Zahra Sa, 2006 & 172 & 817 \\
Cohen Wm, 1990 & 171 & 12,419 \\
Zollo M, 2002 & 168 & 2,264 \\
Penrose E. T., 1959 & 160 & - \\
Winter Sg, 2003 & 158 & 1,491 \\
Lumpkin Gt, 1996 & 157 & 2,797 \\
\hline
\end{tabular}

Source: the Authors (2019).

In order to determine the most productive authors of the sample, we follow PerianesRodriguez, Waltman and Van Eck, (2016) recommendations that suggest that the fractional counting would better demonstrate the most productive authors in comparison to the full counting. By using that approach the most productive authors identified was Teece with 11 articles on the full counting followed by Weerawardena, Wright and Zahra that equate on 7. The other authors (Agarwal, Garcia Villaverde, Mahoney, Ruiz Ortega, Saarenketo) full counted on 6 as described in table 3 .

TABLE 3 - MOST PRODUCTIVE AUTHORS

\begin{tabular}{llll}
\hline Full Counting & & Fractional Counting & \\
\hline Authors & Articles & Authors & Articles
\end{tabular}




\begin{tabular}{llll} 
Teece Dj & 11 & Teece Dj & 8.333 \\
Weerawardena J & 7 & Zahra Sa & 3.250 \\
Wright M & 7 & Anning Dorson T & 3.000 \\
Zahra Sa & 7 & Arend Rj & 3.000 \\
Agarwal R & 6 & Tolstoy D & 2.500 \\
Garcia Villaverde Pm & 6 & Weerawardena J & 2.450 \\
Mahoney Jt & 6 & Foss Nj & 2.250 \\
Ruiz Ortega Mj & 6 & Pitelis Cn & 2.250 \\
Saarenketo S & 6 & Pehrsson A & 2.143 \\
\hline
\end{tabular}

SOURCE: The Authors (2019)

Some differences can be identified between the two methods used. These changes are related to the fact that, as explained by Perianes-Rodriguez, Waltman and Van Eck (2016), in the full counting method a publication co-authored by more than four researchers, for example, has the weight of one. While at the fractional counting, the publication weight is split among the four researchers with a fractional weight of $1 / \mathrm{N}$ (e.g. if a paper has four authors, each one receives $1 / 4$ of the publication, or 0.25 ).

The permanence of the top 10 most cited researches on the field such as Zahra, Wright and Garcia Villaverde can be explained by a phase on entrepreneurship research called 'TakeOff phase', by Landström and Benner (2010). This phase started during the 90s and is known by the migration of scholars from different social sciences disciplines to the field of entrepreneurship, on what is called the "transient researchers" (LANDSTRÖM and BENNER, 2010).

The authors production over time was also analyzed and Teece figures as having most of his publication done in 2014 as it is displayed in figure 2:

FIGURE 2 - TOP 10 AUTHORS PRODUCTION OVER TIME

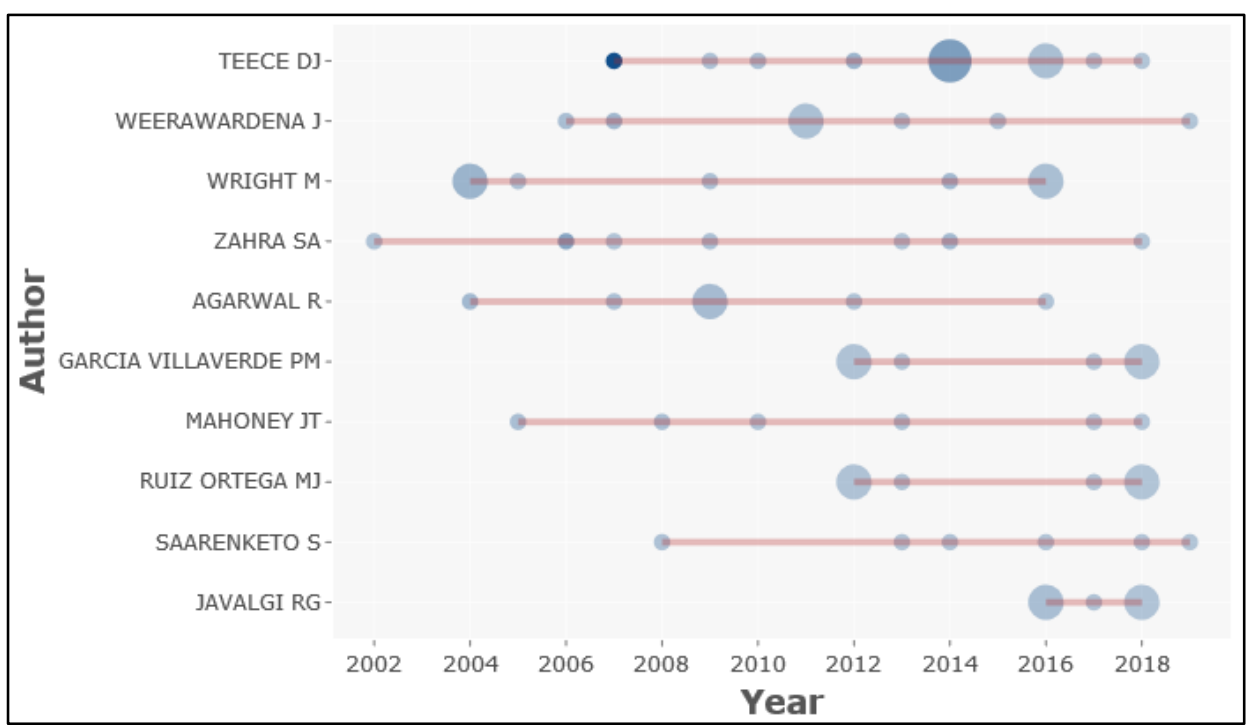

Source: the authors (2019). 
The relationship between the keywords from the 701 papers of the sample was also investigated and a total of 1690 keywords were identified. From these, the bibliometric map on figure 3 shows the 50 most cited keywords which relates to the keywords cited 7 times or more.

FIGURE 3 - BIBLIOMETRIC MAP OF AUTHORS KEYWORDS

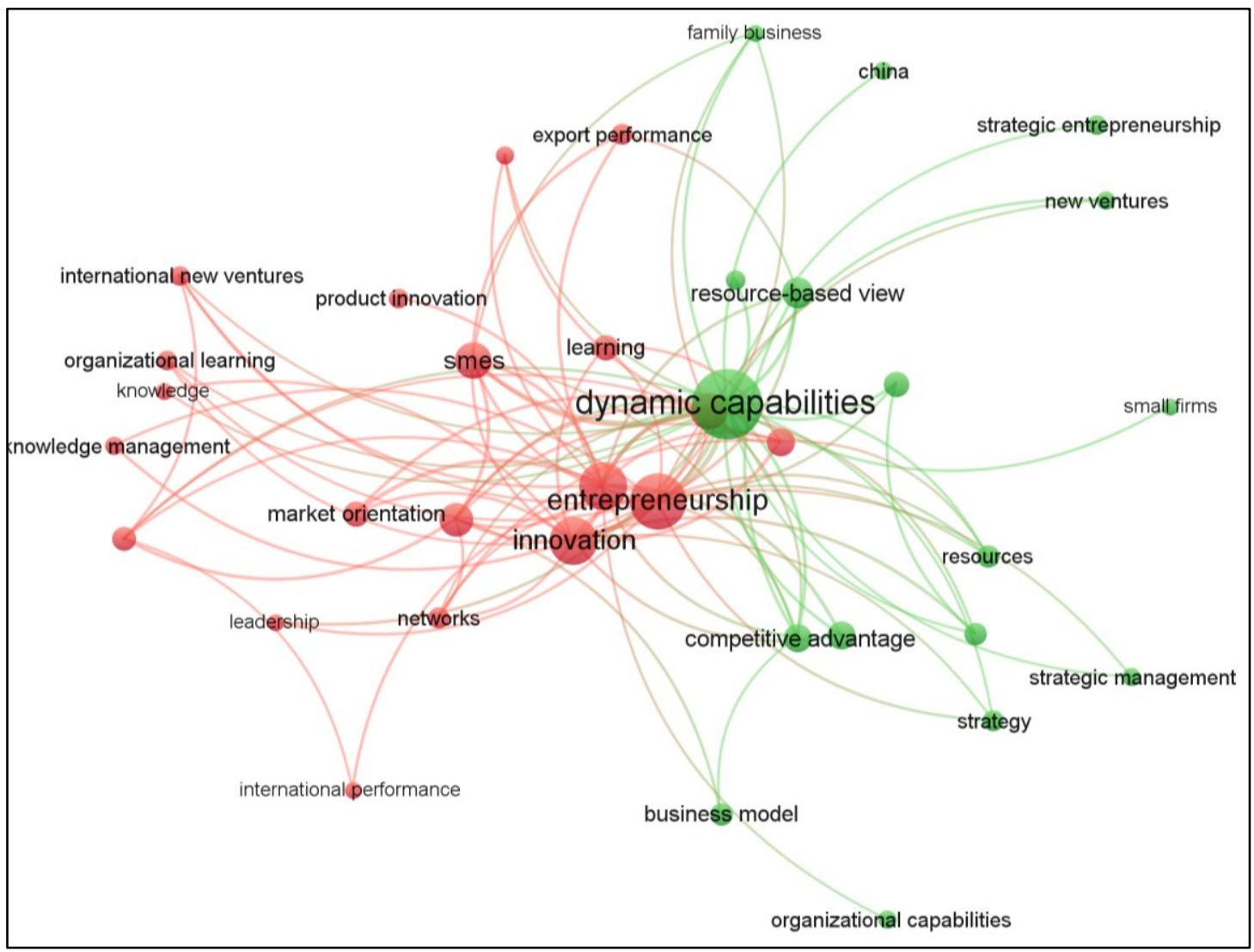

Source: the authors (2019).

From the map we can infer that there are two distinct clusters of keywords. The green one (on right side of the map) contains keywords that are more related to the field of dynamic capabilities, with the term dynamic capabilities displaying 136 occurrences. This cluster also presents the most cited terms such as resource-based view (26), competitive advantage (23), and firm performance (17), subjects that are often related to the organizational strategy aspects and are directly related to the dynamic capability approach.

On contrast, the red cluster (displayed on the left side of the map) displays keywords related to the entrepreneurship with 86 occurrences. In this cluster keywords like entrepreneurial orientation (64), innovation (64), SMEs (36), and internationalization (32) were the most frequent.

Furthermore, it can be noticed that the red cluster has a closer relationship between its keywords, also demonstrating that innovation is directly more related to entrepreneurship than 
with dynamic capabilities, despite the fact that dynamic capabilities are often used to explore innovation at organizations.

In reference of the co-citation analysis it is possible to identify the most 50 cited references of the sample in which Teece's work appears to be of vital importance. Figure 4 presents this part of the analysis:

\section{FIGURE 2 - BIBLIOMETRIC MAP OF CO-CITATIONS}

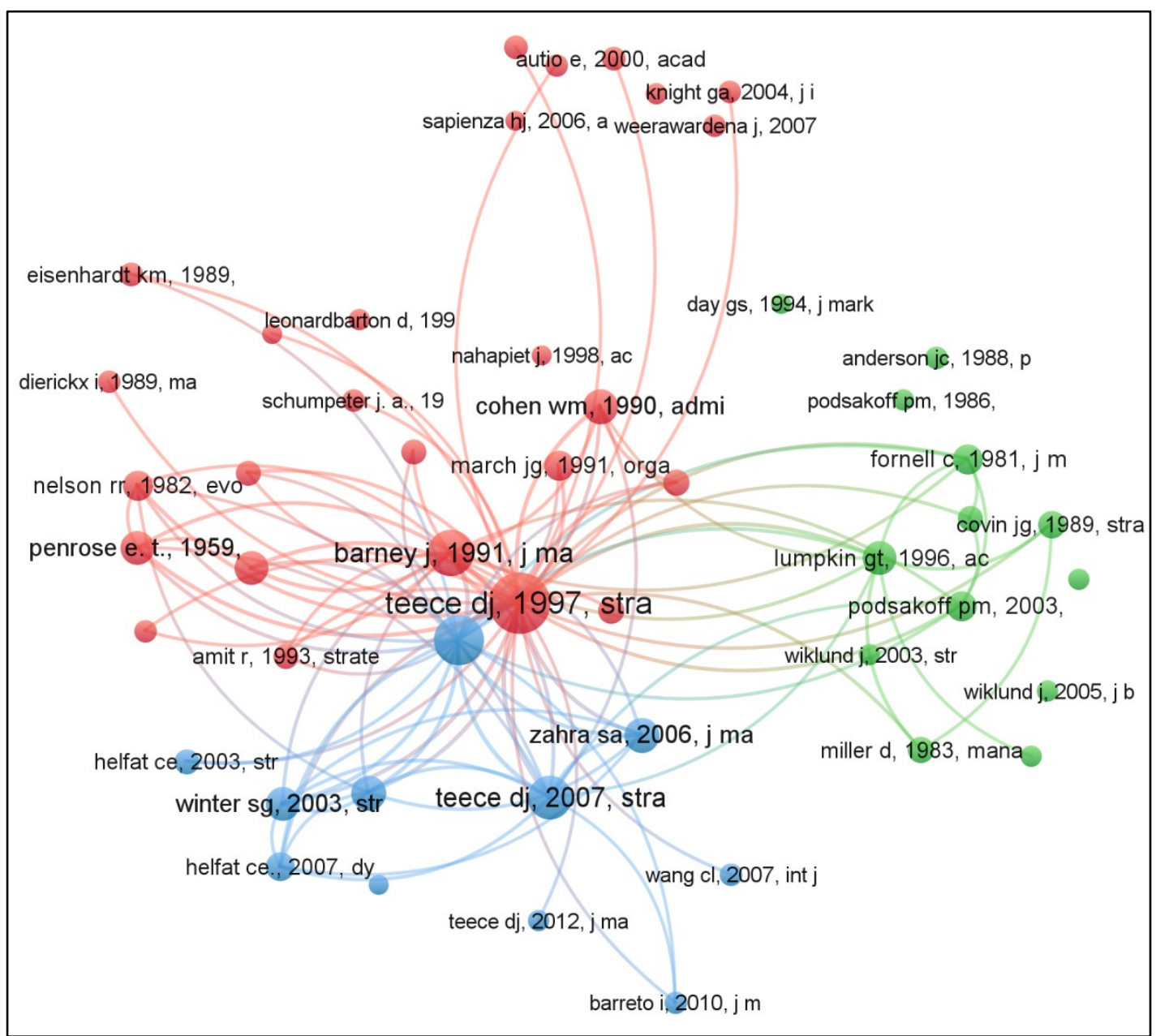

Source: the authors (2019).

Analyzing the co-citations it is possible to divide them into three different clusters. The red one located on the top at the left side includes authors belonging to a classical strategy research stream, such as Nelson (1982), Penrose (1959), and Barney (1991). Those authors represent a group of scholars that influenced the seminal work of Teece, Pisano and Shuen (1997), which represents the most expressive work of the whole analysis. In this sense, this cluster is represented by a predominance of scholars related to the seminal works of dynamic 
capabilities field including scholars form the resource based theory who highly influenced the basis of this approach (BARRETO, 2010).

On the other side of the map (right side on the top) the green cluster can be seen displaying some works more related to the entrepreneurship field, such as Lumpkin (1996), Covin (1989), and Miller (1983). Nevertheless, other authors with researches that do not directly relates to entrepreneurship can also be found in the group such as Fornell (1991) and Covin (1989) that are related to strategy field.

The third cluster is displayed in blue and is in the bottom of the map. This group of authors is the one that presents the most publications that contains both the dynamic capabilities and the entrepreneurship field which are related to the objective of this bibliometric review.

The researches conducted by Teece, (2016) and Zahra, Sapienza, Davidsson (2006) are the rare examples of studies that involves both the field of dynamic capabilities and entrepreneurship exploring their interconnection. Unfortunately for the field, it is important to point out that the propositions made by Zahra, Sapienza, Davidsson (2006) more than 10 years ago were not even empirically tested, despite of their importance to the field and its high number of citations. In such wise it is possible to affirm that an in-depth approach linking entrepreneurship to the light of the dynamic capability approach was not fully explored.

To what concerns Teece's work we can notice that his approach to entrepreneurship is mainly based on the entrepreneurial orientation of the leader (TEECE, 2016; TEECE; PETERATD; LEIH, 2016) which, despite of its unquestionable importance, tends to limit the analysis of the entrepreneurship to the entrepreneur itself.

In this sense we consider that it would be constructive for the growth of the fields if researchers could better explore other aspects involving entrepreneurship and dynamic capabilities such as the interaction of entrepreneurship as a competence and dynamic capabilities or the deep understandings of the microfundations of the companies' dynamic capabilities considering the maturity stage of the venture.

\section{$5 \quad$ Final Considerations}

The results of the present study demonstrate that despite the great number of papers that were identified at the WOS database (701 studies), entrepreneurship and dynamic capabilities are two research streams that still need to have their relationships better explored. Most of the studies found focus whether on entrepreneurship or dynamic capability testifying that there is a gap in the literature concerning the interconnection of the two fields.

As exposed previously, the few authors who addressed both streams focused on the capabilities of the entrepreneur or the main decision maker, leaving an empty space for the understanding of other factors that interrelate these two areas of knowledge. Given the complementary roles of dynamic capabilities and entrepreneurship it is important to advance in the understandings of the topics together in a theoretical and empirical level.

This study contributes to the literature in many ways. First because we offer a unique bibliometric analysis involving entrepreneurship and the dynamic capability theoretical approach. Second because we review the literature on the theme and point the gaps that still remain between these two important areas even though their fields separately have an extant 
literature as demonstrated. Third this analysis aim to motivate and encourage future studies that can explore aspects that go beyond the investigation of the entrepreneur as a decision-maker and their capabilities on leading the firm. We argue that this is a fertile area for both theoretical and empirical studies.

This research has limitations concerning since its quantitative method that do not contemplate a deep analysis of content of the articles to what concerns the fact that only one database was adopt for the study. For this reason, relevant papers may have been missed which could enrich the analysis made. We hope future studies can overcome our constraints and bring advances to this significant area of study.

\section{References}

APRILIYANTI I. D.; ALON I. Bibliometric analysis of absorptive capacity. International Business Review, v.26, n.5, p.896-907, 2017.

ARIA, M.; CUCCURULLO, C. Bibliometrix: An R-tool for comprehensive science mapping analysis. Journal of Infometrics, v.11, n.4, p.959-975, 2017.

BAIER-FUENTES, H.; MERIGO, J. M.; AMORÓS, J. E.; GAVIRIA-MARIN, M. International entrepreneurship: a bibliometric overview. International Entrepreneurship and Management Journal, v.15, p.385-429, 2019.

BARRETO, I. Dynamic capabilities: a review of past research and an agenda for the future. Journal of Management, v. 36, n. 1, p. 256-280, 2010.

BENAVIDES-VELASCO, C. A.; QUINTANA-GARCÍA, C.; GUZMÁN-PARRA, V. F. Trends in family business research. Small Business Economics, v.40, v.1, p.41-57, 2013.

CHABOWSKI, B.; SAMIEE, S. HULT, T. A bibliometric analysis of the global branding literature and a research agenda. Journal of International Business Studies, v.44, n.6, p.622634, 2013.

DAN, M. C.; GOIA, S. I. Entrepreneurship and regional development. A bibliometric analysis. In: Proceedings of the International Conference on Business Excellence. v.12, n.1, p.276-287, 2018.

DAVIDSSON, P., 2005. Researching Entrepreneurship. Springer, New York.

DIODATO, V. Dictionary of bibliometric. Binghamton: Haworth Press, 1994.

DIONISIO. M. The evolution of social entrepreneurship research: a bibliometric analysis.

Social Entrepreneurship Journal, v.15, n.1, p.22-45, 2019.

EISENHARDT, K. M.; MARTIN, J. A. Dynamic Capabilities: What are they? Strategic Management Journal, v.21, p.1105-1121, 2000.

FEREIRA, J. J.; RAPOSO, M. L.; ESTEVÃO, C.; PERIS-ORTIZ, M.; RUEDA-

ARMENGOT, C. The dynamic capabilities perspective of strategic management: a co-citation analysis. Scientometrics, v.112, n.1, p.529-555, 2017.

FERREIRA, J. J. M.; FERNANDEZ, C. I.; RATTEN, V. A co-citation bibliometric analysis of strategic management research. Scientometrics, v.109, n.1, p.1-32, 2016. 
GOMES, L. A. de V.; FACIN, A. L. F.; SALERNO, M. S.; IKENAMI, R. K. Unpacking the innovation ecosystem construct: Evolution, gaps and trends. Technological Forecast \& Social Change, v.136, p.30-48, 2018.

GUTIÉRREZ-SALCEDO, M.; MARTÍNEZ, M. Á.; MORAL-MUNOZ, J. A.; HERRERRAVIEDMA, E.; COBO, M. J. Some bibliometric procedures for analyzing and evaluating research fields. Applied Intelligence, v.48, n.5, p.1275-1287, 2018.

GRIFFITH, D. A.; HARVEY, M. G. A resource perspective of global dynamic capabilities. Journal of International Business Studies, v. 32, n. 3, p. 597-606, 2001.

KÜCHER, A.; FELDBAUER-DURSTMÜLLER, B. Organizational failure and decline - A bibliometric study of the scientific frontend. Journal of Business Research, v.98, p.503-516, 2018.

LANDSTRÖM, H.; BENNER, M. Entrepreneurship research: a history of scholarly migration. In: Historical Foundations of Entrepreneurship Research. (pp. 13-45). Cheltenham: Edward Elgar, 2010.

LANDSTRÖM, H.; HARIRCHI, G.; ASTRÖM, F. Entrepreneurship: Exploring the knowledge base. Research Policy, v.41, n.7, p.1154-1181, 2012.

MCBURNEY, M. K.; NOVAK, P. L. What is bibliometric and why should you care? In: Proceedings of the professional communication conference, p.108-114, 2002.

MOTA, F. B.; PINTO, C. D.; PARANHOS, J.; HASENCLEVER, L. Mapping the 'dynamic capabilities' scrientific landscape, 1990-2015: A bibliometric analysis. Journal of Scientometrics and Information Management, v.11, n.2, 309-324, 2017.

OSAREH, F. Bibliometrics, Citation Analysis, and Co-Citation Analysis. Libri, v.46, p.149158, 1996.

PERIANES-RODRIGUEZ, A.; WALTMAN, L.; VAN ECK, N. J. Constructing bibliometric networks: A comparison between full and fractional counting. Journal of Informetrics, v.10, n.4, p.1178-1195, 2016.

PERSSON, O. The intellectual base and research fronts of JASIS 1986-1990. Journal of the American Society for Information Science, v.45, n.1, p.31-38, 1994.

PETERAF, M.; DI STEFANO, G.; VERONA, G. The elephant in the room of dynamic capabilities: bringing two diverging conversations together. Strategic Management Journal, v. 34, n. April, p. 1389-1410, 2013.

RANDHAWA, K.; WILDEN R.; HOHBERGER, J. A Bibliometric Review of Open Innovation: Setting a Research Agenda. The Journal of Product Innovation Management, v.33, n.6, p.750-772, 2016.

SANTOS, G.; MARQUES, C. S.; FERREIRA, J. A look back over the past 40 years of female entrepreneurship: mapping knowledge networks. Scientometrics, v.115, n.2, p.953987, 2018. 
SARASVATHY, S. D. Causation and Effectuation: Toward a theoretical shift from economic inevitability to entrepreneurial contingency. Academy of Management Review, v.26, n.2, p.243-263, 2001.

SHANE, S.; VENKATARAMAN, S. The promise of entrepreneurship as a field of research. Academy of Management Review, v25, n.1, p.217-226, 2000.

STEFANO, G. D.; GAMBARDELLA, A.; VERONA, G. Technology push and demand pull perspectives in innovation studies: Current findings and future research directions. Research Policy, v.41, n.8, p.1283-1295, 2012.

SUOMINEN A.; SEPPÄNEN, M.; DEDEHAYIR. A bibliometric review on innovation systems and ecosystems: a research agenda. European Journal of Innovation Management, v.22, v.2, p.335-360, 2019.

TEECE, D. J. Explicating Dynamic Capabilities: The Nature and Microfoundations of (Sustainable) Enterprise Performance. Strategic Management Journal, v.28, p. 1319-1350, 2007.

TEECE, D. J. Dynamic Capabilities: Routines versus Entrepreneurial Action. Journal of Management Studies, v. 49, n. 8, p. 1395-1401, 2012.

TEECE, D. J. Dynamic capabilities and entrepreneurial management in large organizations:

Toward a theory of the (entrepreneurial) firm. European Economic Review, v. 86, p. 202-216, 2016.

TEECE, D. J.; PISANO, G. The dynamic capabilities of enterprise: an introduction. Industrial and Corporate Change, v.3, n.3, p.537-556, 1994.

TEECE, D. J.; PISANO, G.; SHUEN, A. Dynamic Capabilities and Strategic Management. Strategic Management Journal, v.18, n.7, p.509-533, 1997.

TEECE, David; PETERATD, Margaret; LEIH, Sohvi. Dynamic Capabilities and Organizational Agility. California Management Review, [s. 1.], v. 58, n. 4, p. 4-9, 2016.

VALLASTER, C.; KRAUS, S. Ethics and Entrepreneurship: A Bibliometric Study and Literature Review. Journal of Business Research, v.99, p.226-237, 2019.

VAN ECK, N. J.; WALTMAN, L. Software survey: VOSviewer, a computer program for bibliometric mapping. Scientometrics, v.84, n.2, p.523-538, 2010.

VOEGEL, R.; GÜTTEL, W. H. The Dynamic Capability View in Strategic Management: A Bibliometric Review. International Journal of Management Reviews, v.15, n.4, p.426-446, 2013.

VOLERY, T.; MAZZAROL, T. The evolution of the small business and entrepreneurship field: A bibliometric investigation of articles published in the International Small Business Journal*. International Small Business Journal, v.33, n.4, p.374-396, 2015.

WERNERFELT, B. A resource-based view of the firm. Strategic Management Journal, v.5. n.2, p.171-180, 1984. 
ZAHRA, S. A.; SAPIENZA, H. J.; DAVIDSSON, P. Entrepreneurship and dynamic capabilities: A review, model and research agenda. Strategic Management and Entrepreneurship, v.43, n.4, p.917-955, 2006.

ZOLLO, M.; WINTER, S. G. Deliberate Learning and the Evolution of Dynamic Capabilities. Organization Science, v. 13, n. 3, p. 339-351, 2002.

ZUPIC, I.; ČATER, T. Bibliometric Methods in Management and Organization.

Organizational Research Methods, v.18, n.3, p.429-472, 2015. 